\title{
Observation on Scientific Development of Our Forest Product Trade from Viewpoints of Trade Dilemma
}

\author{
Xue Xuan-deng, Lan Cong-cong \\ Economics College, Henan University of Science and Technology, Luoyang 471000, China \\ Xue69519@163.com,858779737@qq.com
}

\begin{abstract}
The forest product trade is a very important part in the foreign trade.Under the current situation of increasingly fierce world trade competition and worse trade barriers, the promotion of the scientific development of foreign trade of forest products is an objective requirement of practising the scientific outlook on development. All the relevent data of our forest products in foreign trade from the year 2004 to 2011 have been collected to analyze the current situation and dilemma of our forest product trade, and put forward the measurement to promote the scientific development of forest products in foreign trade.

Index Terms - forest products, foreign trade, dilemma, countermeasure
\end{abstract}

\section{Introduction}

Our country is one of major countries with import and export of forest products. And forest product trade plays a very important part in China's national economy. At present, as US economy is recovering slowly, the impact of European sovereign debt crisis further continues, and foreign trade barriers become increasingly intensified, China's forest product trade is facing more complex international environment. How to promote the scientific development of forest product trade is one of the real problems we will meet with.

\section{The Status Quo of China's Forest Product Trade}

\section{A. Import and Export Scale of Sustained Growth}

often accompanied by trade deficit. In recent years, along with the national macroeconomic regulation and control of the import and export structure, China's foreign trade in forest products has maintained strong growth momentum. Over the eight years from 2004 to 2011, the national import and export forest products have maintained a continuous rapid growth. Trade has been increased by over four folds, from $\$ 25.3$ billion in 2004, up to $\$ 119.1$ billion in 2011, annual increase averaging $24.5 \%$. From an export point of view, the exports have been increased from $\$ 11,3$ million continuously to $\$$ 54.2 billion in 2011, annual growth rate averaging $21.4 \%$, imports have been grown from $\$ 13,9$ million to $\$ 64,9$ million in 2011, an average annual increase of $25.38 \%$, the annual increase by $37.1 \%$, imports have been increased faster than export growth.

From the trade balance, Over the eight years from 2004 to 2011, China's forest products have been in the trade deficit within four years, From 2004 to 2005, our trade deficit began to decline.In 2006 and 2007, the deficit momentum was reversed, i.e. from deficit into a surplus, but the trade deficit was resumed again in 2008, the economic situation had a better turn in 2009 and 2010,changed into a surplus, but resumed into a huge deficit of $\$ 10.7$ billion in 2011. Overall, China's forest product trade is characterized by the instability of the trade balance.

2004 -- 2011 China foreign trade list of forest products unit: 100million USD

\begin{tabular}{|c|c|c|c|c|c|c|c|c|}
\hline Years & 2004 & 2005 & 2006 & 2007 & 2008 & 2009 & 2010 & 2011 \\
\hline $\begin{array}{c}\text { Total } \\
\text { trade }\end{array}$ & 253 & 297 & 374 & 447 & 477 & 597 & 963 & 1191 \\
\hline Exports & 113 & 147 & 190 & 225 & 227 & 346 & 488 & 542 \\
\hline Imports & 139 & 150 & 185 & 221 & 250 & 251 & 475 & 649 \\
\hline $\begin{array}{c}\text { Trade } \\
\text { belance }\end{array}$ & -26.7 & -3.3 & 4.99 & 4.02 & -24 & 95 & 12.9 & -107 \\
\hline
\end{tabular}

Data sources: the FAO database

\section{.B. The Foreign Trade Market Partners Are Based on Traditional Objects}

From the viewpoint of trade objects, for a long period of time, our traditional trade is relatively fixed, and the main export partners include countries such as USA, Japan, the European Union and Australia, the main imports partners are mainly countries such as Russia, the United States, Canada and Indonesia. The United States and the European Union have been the key areas of China's import and export trade of forest products. Take the years 2010 and 2011as an example, in 2010 , China's total trade in forest products was $\$ 96.27$ billion, with the U.S. forest products trade volume of $\$ 17.2$ billion, an increase of $32 \%$, accounting for $17.9 \%$ of the total trade in forest products, of which imports reach $\$ 6.12$ billion, an increase of $48.5 \%$, exports reach $\$ 11.07$ billion, an increase of $25 \%$. The United States is still the biggest country for China's import and export forest product trade, as compared with total trade of European forest product as $\$ 14.4$ billion, increase of $28 \%$, accounting for $15 \%$ of the total trade in forest products, also as compared with total trade of Japanese forest product as $\$ 6.7$ billion, increase of $21 \%$, accounting for $7 \%$ of the total trade in forest products. In 2011, the forest product trade volume between China and the U.S. came to $\$ 17.88$ billion, an increase of approximately $23 \%$, accounting for about $15 \%$ of the forest products in China's total trade, and the forest product trade volume between China and E.U. arrived at $\$$ 20.1 billion, an increase of approximately $19 \%$, accounting for about $16.9 \%$ of China's total trade in forest products. 


\section{Import and Export Products Mainly Concentrated in Wood Products}

From the perspective of product trade, in recent years, China's export of forest products are mainly wood furniture, paper and paperboard-like products, wood products and plywood, The above-mentioned forest product exports reached US $\$ 25.25$ trillion in 2009 , accounting for $69.5 \%$ of forest product exports in 2009 , reaching $\$ 39.11$ trillion in 2010 , accounting for $67.5 \%$ of forest product exports in the year of 2010. Among the national export trade of forest products In 2011, our important forest product exports such as wood furniture, paper products, wood products, plywood, fiberboard and others, maintained the overall upward trend, the momentum of growth higher than the level of the same period in the history, in which plywood and fiberboard are still the main exports. The export volume was increased by $26.8 \%$ and $27.7 \%$, respectively. As far as products are concerned, total exports of wood furniture in 2009 reached $\$ 12.04$ billion, accounting for $33.1 \%$ of the forest product exports in 2009 , total exports in 2010 reached $\$ 16.16$ billion, accounting for $33.1 \%$ of the forest product exports in 2010. It can be seen that wood furniture exports have been developed more stablely in the past two years. The total exports of paper and paperboard products in 2009 were $\$ 7.57$ billion, accounting for $20.8 \%$ of the forest products exports in 2009, total exports in 2010 reached $\$ 9.56$ billion, accounting for $19.5 \%$ of the total forest products exports in 2010, a decrease of $1.3 \%$ compared with those in 2009. The total exports of wood products in 2009 reached $\$ 3.12$ billion, accounting for $6.9 \%$ of the forest product exports in 2009 , the total exports in 2010 coming to $\$$ 3.83 billion, accounting for $7.8 \%$ of the forest product exports in 2010, an increase of $0.9 \%$ compared with those in 2009 . The total export volume of plywood in 2009 was $\$ 2.52$ billion, accounting for $6.9 \%$ of the forest products exports in 2009 , the total exports in 2010 reaching $\$ 3.4$ billion, accounting for $6.97 \%$ of the forest product exports in 2010 , a slight change as compared with that in 2009.

In the import aspect, logs, sawn timber, paper and paperboard products, paper pulp, waste paper, natural rubber and palm oil, etc. are the main sources of imports. The abovementioned forest product imports reached US \$39.11 trillion, accounting for $82.3 \%$ of the total amount of forest product imports. In 2011, the imports of five major kinds of raw wood materials such as wood planks, logs, sawn timber, pulp, and waste paper were increased remarkably, reaching a new record in history, of which the import of waste paper was increased more rapidly. The reasons why it did so were serious shortage of China's domestic wood pulp, and meanwhile the import of waste paper was much cheaper than imported wood pulp.

\section{The Difficulties Faced by China's Forest Products Trade}

\section{A. High Concentration in the Export Market, and Constant Trade Friction}

From 2004 to 2011, except in 2008, China's export market of forest products has been monopolied by the United States,
Japan, Hong Kong, accounting for $60 \%$ share of exports of wood forest products. Among the U.S. imports of wood-based panels, wood floors and furniture and other wood processing products, Chinese products accounted for almost 50\% market share ${ }^{[1]}$. In recent years, the EU's market share began to rise and occupy an important position in China's trade in forest products, and at the same time, forest product trade cooperations between China and developing countries are gradually strengthened, but the export concentration remains very high in the traditional export markets of Japan, Hong Kong, United States. Such large quantities of products flock to more relatively concentrated market, and also naturally meet with the trade friction ${ }^{[1]}$.

The high concentration of export markets reduces anti-risk ability of the export trade of China's forestry industry. In the past decade, China's exports of forest products were highly concentrated in a few developed countries in Europe and America, which caused the domestic enterprises to suffer from the severe impact of the financial crisis in 2008. Several countries constantly set obstacles to prevent Chinese forest products from entering the market, in order to protect its own interests and other reasons because of high dependence on these countries' markets. For example, Chinese exports of furniture to the United States market accounted for $60 \%$ of total exports, while the United States took anti-dumping action on Chinese furniture in 2006. And the United States of America, the European Union and Japan frequently took advantage of such tricks as anti-dumping, technical barriers to impede Chinese forest product exports, such as the EU antidumping case of plywood in July 2003, the United States "337" act of wood floors in 2005, all of which have a serious impact on China's export trade of forest products.

\section{B. Imperfect Forestry Industry Chain}

Forestry industry chain is a chain of many industries.In our forestry industry chain upstream, due to our not enough efforts to support forest cultivation, a stable and efficient financial support channels has been seriously lacked. In species cultivation, our technical reserves are running short, lacking effective scientific and technological support, so that species research and development work are seriously lagging behind in China. And at the same time, our forestry development strategy focuses on the protection of forest resources and improvement of the ecological environment, thus causing more shortage of forest resources. So in the forestry industry chain most of China's forest sources rely on imports, and increasingly more imports, so that the processing enterprises are encountering more risks.

In the middlestream link, first of all, the Forest Product Associations at all levels in China have not played their due role. The establishment of industry associations is a commonly-applied form of international community. Under the free trade market economy conditions, many problems are unable to be solved by individual enterprises, only by dependence on the conservation and development of interests of the industry trade associations, communication between 
enterprises and government to deal with foreign-related economic disputes, coordination between production and business activities in the same industries and enterprises. China's forestry enterprises are lacking the industry associations who can be responsible for competition and cooperation. Secondly, the majority of China's forest product manufacturing enterprises have been developed on the basis of small household workshops, so smaller and obsolete equipment in thses private enterprises has resulted in inherent vulnerability in the growth process. It is difficult to resist the economic risks brought about by the deterioration in trading conditions. Again, simple processing corporate profit margins gets more narrow, they are not easy to grow and develop.

In the downstream link, firstly, China's exports of forest products market are highly concentrated, this point in the paper mentioned has already mentioned above and will not be discussed too much. Secondly, the forest products from other developing countries have given rise to the impact on China's exports of forest products. Finally, China's forest products export-oriented economic development model is facing the end of exposure. On forestry largest consumer is the United States, after the financial crisis, due to the depreciation of the U.S. dollar and securities defaults of sub-prime mortgage crisis has led to China's foreign exchange reserves due to the considerable part of the dollar value may be or is being rapidly devalued.

\section{Constraint of International Timber Harvesting Policy to China's Forest Product Trade}

The United States began to implement the Lacey Act Amendment since 2009, which regulates that raw materials for plants and related products shall be prevented from being bought from the National Park, forest reserve, officially designated area, otherwise, the plants and their products will not be allowed to be imported into the United States of America, and the imports dealers will also be subject to administrative, criminal punishment. Following the United States, the European Union passed the new wood act in October 2010. The new EU Timber Regulation Acts shall be implemented in March 2013 to require that all timber products entering the EU market possess legitimacy, all manufacturers of timber products to the EU must be based on the supply and marketing chain of custody records available to support the legitimacy verification. In the long run, the international timber harvesting policy, as an important trading environment factor, will bring many positive effects.

\section{Scientific Development Measures to Promote Trade in Forest Products in China}

A. The Implement of Market-diversified Development, and Strengthening Cooperation With Emerging Economies

The forestry export enterprises in China should consolidate existing trade partners and the market at the same time, under the prosperous situation of our government policy for developing the vast market of Asian and African countries, market-diversified strategy should be implemented, the cooperation with the forest product trade in emerging markets and developing countries strengthened, so as to expand space for development and potential in developing countries, expand exports, and avoid the market risk caused by the highly concentrated export target market.

First of all, our country should formulate and implement the measures of forest product export market-diversified strategy policy, provide policy support and guidance for enterprises to develop new markets, to support the market development by providing financial support and fund guarantee to all kinds of enterprises. Secondly, the service system of foreign trade public information should be established, so as for the enterprises to open up the markets to provide domestic and international information free of charge.Thirdly, the international exhibitions of forest products should be actively organized to expand our product influence, and promote the development of new markets. Lastly, the imbalance issues of bilateral trade between our nation and some developing countries should be dealt with well, in order to reduce development resistance,etc.

\section{B. Perfection of Forestry Industry Chains in China}

In the upstream of forestry industry chains, first of all, our government should support the establishment of cooperative research groups, accelerate the forestry breeding process, secondly, in view of the weak support of forest resource of Chinese forestry industry, slow construction of raw material bases, and much dependence on imports of raw materials, the Chinese government should encourage the national enterprises to take advantage of the appreciation of the Chinese currency, to go abroad for the investment or cooperation, and to create overseas forest resource base for control of the resources. In addition, in other emerging trade areas of South America, Africa, rich in forest resources, but lack of funds and technology, China can seek cooperation with them over the advantages of the capital and technology. Forest resources such as Russia, Brazil, Malaysia, Indonesia and some other countries are rich, but the production level of high value-added forest products is not high, it is urgent to introduce foreign capital to improve industrial competitiveness. China should take this opportunity, and strengthen the cooperation with these countries. In addition, in some countries, rich in forest resources, but in need of further improvement of foreign affairs and trade with China, or with the tight control of blockade by Western powers, or social and political instability, the cooperating conditions are not ripe, so that the bilateral relations should be strengthened, information collected, the strategy investigated, and the conditions created for timely intervention, such as India, and so on.

In the midstream of forestry industry chains, first of all, the role of forest product industry associations should be brought into full play. Industry associations have to strengthen the collection of information, and do the role of a bridge between the government and enterprises, macro-guidance has to be strengthened to change disorderly competition within industries, the intensity of guidance has to be increased to 
popularize relevent legal standard for the enterprises, and to actively participate in trade negotiations, and act as business representatives and so on. Second, the government should encourage enterprises to go out and participate in a variety of exhibitions, to improve the visibility of our forest products, and to increase market share. At the same time, the strategy of establishment and creation of brand names have to be imlemented, the awareness of brand names strengthened to accelerate the construction of brand-name products, by relying on science and technology, product development has to be strengthened, higher value-added forest products have to be exported to increase profit margins, and optimize the structure of export of forest products, so that our forest product exports have to be transformed from comparative advantage to competitive advantage.

In the downstream of forestry industrial chains, forestry enterprises in China should expand its living space in the international market through a variety of means. Firstly, Chinese enterprises can be combined with foreign forestry enterprises, in order to bypass the foreign trade restrictions and non-tariff barriers, the effective way to occupy that nation's market is the way our enterprises should be jointed or cooperated with the foreign forestry companies. Secondly, when the domestic enterprises have insufficient international experience in participating in international bidding, especially in the early stage into the international market, they should perform collaborative bidding or cooperative management with experienced cross-national forestry companies, thirdly, joint ventures should be carried out to expand direct foreign investment businesses.

\section{Government and Businesses Work Together and Actively Respond to Trade Barriers}

Enterprises actively responding to foreign trade barriers in forest products.First of all, in the face of forest product trade friction and disputes, Chinese enterprises should actively respond to and fight for unfair treatment for Chinese enterprises and unreasonable demands, safeguarding their own rights and interests through negotiations or legal means. Secondly, China's forestry enterprises should, under the guidance of the national and trade associations, accelerate the transformation and upgrading of enterprise technology, standardize forest product production and processing, and create several famous brand products, which is the most fundamental way China's enterprises break the trade barriers. Thirdly, enterprises can take the overseas investment. Part of China's key forestry enterprises have been in the foreign investment, as for foreign trade barriers in forest products, China's forest product export enterprises can take the "circuitous tactics", through the implementation of joint venture, sole investment or acquisition methods in foreign countries, multinational operation, so as to enhance the international competition ability of China's forest products. Lastly, the cultivation of international talents should be strengthened, so that they can possess an international vision, proficiency in foreign language and good communication skills. They will also be familiar with the rules of WTO and international norms.

The Government playing an active role.First of all, the government should further improve laws and standards systems. For example, in dealing with the trade environment pressure that the forest certification, "Lacey Act" and the EU "timber regulation" have brought about, the single enterprise strength is limited. Therefore, the government should formulate the forest product certification, and chain of custody certification system of forest product on the basis of green standard, and actively seek international certification system recognition, or seek mutual recognition with the trading partner. The government should not only establish a set of international standards and certification system, but also strengthen communication with the target market of the public. The country should take the lead in carrying on public relations so as to open foreign markets of forest products. Secondly, the effective supervision mechanism of forest product exports will be established. The relevant departments should strengthen inspection efforts, strictly inspect the products according to export standards, so as to ensure the last export pass of forest products. Thirdly, multilateral, bilateral communication, negotiations and cooperation should be strongly strengthened. Through various channels and means, rational, strong, polite communication, dialogues and negotiations require the export object countries from Chinese forestry products to adjust or cancel the unreasonable trade restriction measures of China's forest products. Fourthly, the industry information security supervision should also be greatly strengthened.

\section{References}

[1] Yang Lihua, Yin Shaohua. The difficulties and Countermeasures of Chinese forest product trade under the new situation. forestry economy .2011 (4).

[2] Huang Yingli,Cang Yanan, Li Aiqin. China forest product trade status and countermeasure analysis at the stage of the post-financial crisis. The world agriculture.2012 (3).

[3] Zou Wangkun, Ouyang Xuhui, Zou Yue, He Hong, Huang Jun. Trade status and countermeasures of China's forest products in the international financial crisis. Hunan forestry science and technology.2009 (3).

[4] Zhang Han, Nie Ying, Zhang Zhiguang. The effect of the financial crisis on China's forest products export . Forestry Science.2011 (12).

[5] Jia Xiangxiang, Shi Feng, Wu Shengfu, Guo Quanyi, Wang Lijuan. Foreign trade barriers and strategies of China's forest products . Forestry Industry.2011 (4).

[6] Lan Zhanzhan, Wang Liqun. Studies on China's forestry industry chain integration . Journal of Beijing Forestry University.2011 (1). 